IZA DP No. 10145

Can Authorization Reduce Poverty among

Undocumented Immigrants? Evidence from the Deferred Action for Childhood Arrivals Program

Catalina Amuedo-Dorantes

Francisca Antman

August 2016 


\title{
Can Authorization Reduce Poverty among Undocumented Immigrants? Evidence from the Deferred Action for Childhood Arrivals Program
}

\author{
Catalina Amuedo-Dorantes \\ San Diego State University \\ and IZA \\ Francisca Antman \\ University of Colorado Boulder \\ and IZA
}
Discussion Paper No. 10145
August 2016

IZA

P.O. Box 7240

53072 Bonn

Germany

\author{
Phone: +49-228-3894-0 \\ Fax: +49-228-3894-180 \\ E-mail: iza@iza.org
}

\begin{abstract}
Any opinions expressed here are those of the author(s) and not those of IZA. Research published in this series may include views on policy, but the institute itself takes no institutional policy positions. The IZA research network is committed to the IZA Guiding Principles of Research Integrity.

The Institute for the Study of Labor (IZA) in Bonn is a local and virtual international research center and a place of communication between science, politics and business. IZA is an independent nonprofit organization supported by Deutsche Post Foundation. The center is associated with the University of Bonn and offers a stimulating research environment through its international network, workshops and conferences, data service, project support, research visits and doctoral program. IZA engages in (i) original and internationally competitive research in all fields of labor economics, (ii) development of policy concepts, and (iii) dissemination of research results and concepts to the interested public.
\end{abstract}

IZA Discussion Papers often represent preliminary work and are circulated to encourage discussion. Citation of such a paper should account for its provisional character. A revised version may be available directly from the author. 


\section{ABSTRACT}

\section{Can Authorization Reduce Poverty among Undocumented Immigrants? Evidence from the Deferred Action for Childhood Arrivals Program*}

We explore the impact of authorization on the poverty exposure of households headed by undocumented immigrants. The identification strategy makes use of the 2012 Deferred Action for Childhood Arrivals (DACA) program, which provided a temporary work authorization and reprieve from deportation to eligible immigrants. Using a difference-indifferences approach, we compare DACA-eligible to DACA-ineligible likely unauthorized immigrants, before and after the program implementation. We find that DACA reduced the likelihood of life in poverty of households headed by eligible individuals by 38 percent, hinting at the gains from even temporary authorization programs.

JEL Classification: J15, I32

Keywords: immigration, poverty, DACA

Corresponding author:

Francisca M. Antman

Department of Economics

University of Colorado Boulder

256 UCB

Boulder, CO 80309

USA

E-mail: francisca.antman@colorado.edu

\footnotetext{
"We thank Kelly Bedard, Sarah Bohn, Brian Cadena, Seema Jayachandran, Terra McKinnish, Anita Alves Pena, Audrey Singer, Stephen J. Trejo, seminar participants at the University of Southern California and Colegio de la Frontera, along with session participants at the annual meetings of the Population Association of America, Western Economic Association International, and American Economic Association for their helpful comments and suggestions on an earlier draft.
} 
Immigration policy continues to be the subject of heated debate in American politics, the media and the public at large. One of the most contentious issues in the 2016 presidential election is whether immigration reform should include a path to citizenship for unauthorized immigrants in the United States -a population estimated at about 11.7 million in 2012 (Passel et al. 2013). Special attention has been paid to the legality of President Obama's executive orders. First among those orders is the 2012 Deferred Action for Childhood Arrivals (DACA) program, which offers eligible immigrants a renewable two-year reprieve from deportation proceedings and work authorization. ${ }^{1}$

To explore the impact of authorization on the welfare of likely unauthorized immigrants, we use a quasi-experimental approach that focuses on the intent to treat and exploits the somewhat arbitrary criteria determining DACA eligibility. Our emphasis is on poverty given that unauthorized immigrants face poverty rates nearly twice as large as those of U.S.-born individuals (Passel and Cohn 2009). While unauthorized immigrants are especially vulnerable, their households are also home to millions of citizen children.

Our identification strategy relies on the following observable criteria determining DACA eligibility: being younger than 31 years old in 2012, having arrived to the United States before age 16 and prior to 2007, and having the equivalent of a high school diploma or beyond. Specifically, we exploit differences in one eligibility rule: being under the age of 31 in 2012, and compare individuals who share all other observable eligibility criteria. The sole difference between respondents in the treatment and controls groups is that the former were slightly

\footnotetext{
${ }^{1}$ According to U.S. Citizenship and Immigration Services (USCIS, http://www.uscis.gov), an individual eligible for DACA must: (1) Be under the age of 31 as of June 15, 2012; (2) Have arrived in the United States before reaching his $16^{\text {th }}$ birthday; (3) Have continuously resided in the United States since June 15, 2007; (4) Have been physically present in the United States on June 15, 2012; (5) Have entered without inspection prior to June 15, 2012, or had his lawful immigration status expired by that date; (6) Be currently in school, have graduated from high school or obtained an equivalent degree, or have been honorably discharged from the Coast Guard or Armed Forces of the United States; and (7) Have no criminal records or pose a threat to national security or public safety.
} 
younger in 2012. Flexible controls for age and other observable characteristics further ensure that the estimated DACA impact is not due to differences in age or other individual traits.

We find evidence that DACA reduced the incidence of poverty by about 38 percent for eligible individuals. Our finding adds to a long-standing literature examining the impact of legalization under the 1986 Immigration Reform and Control Act on immigrants (e.g. AmuedoDorantes et al., 2007), with the important distinction that DACA only offers a temporary reprieve and work authorization and the program's continuity depends on the executive branch. In addition, our finding complements an emerging literature examining the schooling, labor market and criminal implications of DACA (Amuedo-Dorantes and Antman forthcoming, Pope 2015). Learning about the impact of DACA on poverty offers valuable lessons for future and pending immigration initiatives, such as the 2014 expansion of DACA and the Deferred Action for Parents of Americans and Lawful Permanent Residents (DAPA) -both currently blocked from implementation by federal courts.

\section{Data and Descriptive Evidence}

To provide the most robust estimate of the impact of DACA, we focus on a narrow window around its implementation and use the 2009 through 2014 waves of the American Community Survey (ACS). Unfortunately, the ACS does not inform on the survey month. Since DACA was announced in June 2012 and numerous applications were received between August and December 2012 (DHS 2014), we drop the data for 2012 and use 2013 and 2014 as the DACA treatment years. In addition to its representativeness, an advantage of working with the ACS is that it provides detailed information on the ratio of each individual's family income to the poverty line for a family of similar composition. Using that information, we construct two poverty indicators measuring whether the family's income is below: (a) the poverty line, and (b) 
one and half times the poverty line (e.g. Bailey et al. 2014). These two indicators allow us to gauge the extent to which DACA might have impacted the exposure to acute and near poverty. ${ }^{2}$

One important limitation of the ACS is that it lacks sensitive information on the legal status of migrants. Thus, we rely on ethnicity and citizenship traits, which have been shown to be good predictors of migrants' unauthorized status (Passel and Cohn 2009), and focus our attention on Mexican non-citizens. All respondents meet the following criteria: having at least a high school level equivalent education and arriving to the United States prior to 2007 at an age below 16. By limiting the age window to those between 27 and 34 years of age, we also restrict attention to those in close proximity to the age-eligibility threshold. ${ }^{3}$ Finally, we focus on household heads, as they are likely to have the greatest impact on the family's poverty status.

Table 1 provides descriptive statistics of our sample of 3,573 likely unauthorized household heads, of whom 42 percent fulfilled all of the observable DACA eligibility criteria noted earlier. Importantly, 28 percent of them lived in poor households. The incidence of near poverty was also high, with 47 percent living in households with family incomes that fell below 1.5 times the poverty line. By design, the mean age was close to the DACA threshold of 31 years of age (30.2) and the average age at migration was nine. About 52 percent were men, 63 percent were white, and 52 percent were married. Due to DACA's educational requirements, 70 percent of our sample had a high school-level education and 30 percent exceeded that educational attainment. On average, households had close to four family members. About 20

\footnotetext{
${ }^{2}$ The official poverty indicator presents some drawbacks (Bitler, Hoynes, and Kuka 2014). One is that it likely understates economic need. Thus, we also look at near poverty. In addition, the poverty line does not vary geographically, despite being inflation adjusted; hence we include state fixed-effects and state-time trends to capture differences in the cost of living across states. Finally, the poverty line only refers to money income before taxes. It does not include capital gains or noncash benefits. This is not likely to prove of relevance in our case given likely unauthorized immigrants appear less likely to apply for such benefits owing to their undocumented status (Watson 2014).

${ }^{3}$ These limitations imply that our estimate is specific to a sample of relatively educated individuals who arrived at young ages. While some may be concerned about the external validity of this assessment, DACA limited authorization to similar groups.
} 
percent and 78 percent of immigrants, respectively, lived in states with some interior immigration enforcement or offering in-state tuition for undocumented immigrants. Unemployment rates in their states averaged 8.5 percent.

Table 2 reports difference-in-difference estimates of the impact of DACA on the wellbeing of Mexican non-citizens by exploring the change in the poverty exposure of DACAeligible household heads from before to after the program announcement, relative to the change experienced by their non-eligible counterparts. DACA appears to have served as a protective factor, as the non-eligible became 6.5 percentage points more likely to live in poverty, whereas their eligible counterparts did not. Hence, DACA eligibility is associated with a 9.3 percentage points or 33 percent reduction in the incidence of poverty. The point estimate for 'near poverty' is also negative, albeit not statistically different from zero.

\section{Methodology}

To examine the impact of DACA on poverty, we estimate equation (1) via OLS:

(1) $Y_{i s t}=\alpha+\beta_{1}\left(D_{A C A_{t}} \times\right.$ eligible $\left._{i s t}\right)+\beta_{2}$ eligible $_{i s t}+X_{i s t} \gamma+Z_{s t} \lambda+\mu_{s}+\delta_{t}+\theta_{s} t+\varepsilon_{i s t}$,

where $Y_{\text {ist }}$ indicates whether individual $i$ in state $s$ in year $t$ heads a household with a family income below the standard poverty line. We also consider the likelihood that family income lies below 1.5 times the poverty line as an alternative outcome. $D A C A_{t}$ is a dummy variable equal to 1 in 2013-14 and 0 otherwise. Because equation (1) is estimated on Mexican foreign-born noncitizen household heads between 27 and 34 years old, who arrived prior to 2007 and meet the age-at-arrival and education eligibility criteria, the eligible $_{i s t}$ dummy refers to the only DACA eligibility distinction between the treatment and comparison groups -that is, whether the individual was under the age of 31 in 2012. To ensure that the returns to eligibility are not driven by differences in age, the vector $X_{i s t}$ includes age fixed effects as control variables. In 
addition, we control for age-at-arrival fixed effects, family size, having more than a high schoollevel education, gender, race and marital status. Other controls in $Z_{s t}$ include the state unemployment rate, an indicator for the level of immigration enforcement in the state where respondents reside, ${ }^{4}$ and a dummy for whether the state grants in-state tuition to undocumented immigrants. Finally, equation (1) incorporates state fixed effects $\left(\mu_{s}\right)$, year fixed effects $\left(\delta_{t}\right)$, and state-specific linear time trends $\left(\theta_{s} t\right)$ to address any other policies and economic conditions varying at the state level and possibly afflicting poverty. ${ }^{5}$ All regressions use survey weights and cluster standard errors at the state level. The parameter of interest is $\beta_{1}$, which measures the change in the likelihood of life in poverty (or near poverty) of DACA-eligible household heads after the program went into effect, relative to the change experienced by their likely unauthorized, DACA-ineligible counterparts over the same time period.

\section{Assessing the Impact of DACA on Poverty}

Table 3 presents the results of estimating equation (1) on our sample. As in Table 2, we find that DACA reduced the incidence of poverty by 10.6 percentage points or, approximately, 38 percent of the sample average. ${ }^{6}$ Because this is the lowest poverty bound, this estimated impact is also the largest and, while also negative, DACA does not appear to have significantly lowered the likelihood of living near poverty.

Our empirical strategy assumes that the treatment (DACA-eligible) and control (likely unauthorized DACA-ineligible) groups would have maintained parallel trends in the absence of treatment (DACA). ${ }^{7}$ To investigate if that was the case, we interact the indicator for DACA

\footnotetext{
${ }^{4}$ We create a dummy variable equal to 1 if the state implemented an employment verification (E-Verify) mandate, an omnibus immigration law or signed a state-wide 287(g) agreement with Immigration Custom Enforcement (ICE).

${ }^{5}$ Note that the inclusion of year fixed effects absorbs the main level effect of DACA $\left(D A C A_{t}\right)$ in the equation.

${ }^{6}$ State and year fixed-effects, as well as state-time trends, are by and large statistically significant.

7 Additionally, we assume any unobserved time-varying group effects are captured by the controls and treat individual-level observations as independent.
} 
eligibility with year indicators for each of the years prior to DACA in our sample $(2009,2010$, and 2011), and add these interaction terms to the right-hand-side of equation (1). We graph the resulting coefficients and confidence intervals, as well as the coefficient of interest $\left(D A C A_{t} \times\right.$ eligible $_{\text {ist }}$ ) in Figure 1. The results show no statistically significant impact of DACA eligibility prior to DACA's implementation as the confidence intervals on the coefficient estimates corresponding to the eligibility indicator interacted with those years prior to DACA's implementation always include zero. In fact, it is only in the post-DACA period that a decline in poverty is observed for the DACA-eligible relative to the ineligible comparison group. Thus, the estimated impact of DACA in Table 3 is not likely to be biased by pre-existing trends.

\section{Conclusion}

Despite the short time period during which DACA has been in place and the uncertainty surrounding its durability, we find that authorization has allowed the families of DACA-eligible household heads to escape poverty. This finding supports the view that even temporary authorization programs, such as the expansion of DACA and DAPA -both currently blocked from implementation, confer important benefits to participants, their families and, in turn, their communities. The question remains whether the DACA program will continue after the upcoming presidential election and, if it does, whether its long-run impacts will differ. 


\section{References}

Amuedo-Dorantes, Catalina and Francisca Antman. Forthcoming. "Schooling and Labor Market Effects of Temporary Authorization: Evidence from DACA." Journal of Population Economics.

Amuedo-Dorantes, Catalina, Cynthia Bansak, and Steven Raphael. 2007. "Gender Differences in the Labor Market: Impact of IRCA's Amnesty Provisions." American Economic Review, 97(2): 412-16.

Bailey, M. J., O. Malkova, and J. Norling. 2014. "Do Family Planning Programs Decrease Poverty? Evidence from Public Census Data." CESifo Economic Studies 60 (2): 312-37. doi:10.1093/cesifo/ifu011.

Bitler, Marianne, Hilary Hoynes, and Elira Kuka. 2014. "Child Poverty and the Great Recession.” Innocenti Working Paper No. 2014-11, UNICEF Office of Research, Florence.

Department of Homeland Security, USCIS, Biometrics Capture Systems, CISCOR. 2014. At: http://www.uscis.gov/sites/default/files/USCIS/Resources/Reports\%20and\%20Studies/Immigrati on\%20Forms\%20Data/All\%20Form\%20Types/DACA/DACA_fy2014_qtr3.pdf [12/2/2015].

Passel, Jeffrey S. and D'Vera Cohn. 2009. A Portrait of Unauthorized Immigrants in the United States. Washington DC: Pew Hispanic Center.

Passel, Jeffrey S., D'Vera Cohn, and Ana Gonzalez-Barrera. 2013. "Population Decline of Unauthorized Immigrants Stalls, May Have Reversed." Washington, D.C., Pew Research Center. September 23, 2013.

Pope, Nolan G. 2015. The Effects of DACAmentation: The Impact of Deferred Action for Childhood Arrivals on Unauthorized Immigrants." Unpublished Manuscript. University of Chicago.

Watson, Tara. 2014. "Inside the Refrigerator: Immigration Enforcement and Chilling Effects in Medicaid Participation.” American Economic Journal:Economic Policy 6 (3): 313-38. 
Table 1: Summary Statistics

[Sample: Skilled (HS+) Mexican Non-citizens 27-34 Years of Age Who Arrived Prior to Age 16]

\begin{tabular}{lcc}
\hline Statistic: & Mean & S.D. \\
\hline Poverty Measures: & & \\
Living in Poverty & 0.281 & 0.449 \\
Living in Near Poverty & 0.467 & 0.499 \\
Independent Variables: & & \\
DACA Eligible & 0.424 & 0.494 \\
Age & 30.226 & 2.244 \\
Age at Arrival & 9.058 & 4.773 \\
Male & 0.519 & 0.500 \\
White & 0.630 & 0.483 \\
Black & 0.005 & 0.070 \\
Married & 0.521 & 0.500 \\
High School & 0.704 & 0.456 \\
More than High School & 0.296 & 0.456 \\
Family Size & 3.740 & 1.780 \\
Any State Immigration Enforcement & 0.201 & 0.401 \\
In-state Tuition Policy State & 0.780 & 0.414 \\
State Unemployment Rate & 8.535 & 2.167 \\
Observations & & 3,573 \\
\hline
\end{tabular}

Notes: "Living in Poverty" refers to living in a household with a family income below the poverty line, whereas "Living in Near Poverty" refers to living in a household with a family income below 1.5 times the poverty line.

Source: Authors' tabulations using the ACS 2009-2011, 2013-2014. 
Table 2: Descriptive Differences-in-Differences Estimates of the Impact of Household Head DACA-Eligibility on Household Poverty [Sample: Skilled (HS+) Mexican Non-citizens 27-34 Years of Age Who Arrived Prior to Age 16]

\begin{tabular}{|c|c|c|c|c|c|c|c|c|c|c|}
\hline & \multicolumn{4}{|c|}{ DACA Eligible } & \multirow{2}{*}{\multicolumn{3}{|c|}{ Non DACA-Eligible }} & \multicolumn{3}{|c|}{ DD } \\
\hline & Pre-DACA & Post-DACA & DT & $\mathbf{N}$ & & & & $\mathbf{N}$ & (DT-DC) & $\mathbf{N}$ \\
\hline Living in Poverty & $\begin{array}{c}0.302 \\
{[0.460]}\end{array}$ & $\begin{array}{c}0.275 \\
{[0.447]}\end{array}$ & $\begin{array}{c}-0.028 \\
(0.030)\end{array}$ & 1,490 & $\begin{array}{c}0.257 \\
{[0.437]}\end{array}$ & $\begin{array}{c}0.322 \\
{[0.468]}\end{array}$ & $\begin{array}{c}0.065^{* * *} * \\
(0.024)\end{array}$ & 2,083 & $\begin{array}{c}-0.093 * * * \\
(0.025)\end{array}$ & 3,573 \\
\hline Living in Near Poverty & $\begin{array}{c}0.477 \\
{[0.500]}\end{array}$ & $\begin{array}{c}0.461 \\
{[0.499]}\end{array}$ & $\begin{array}{c}-0.016 \\
(0.028)\end{array}$ & 1,490 & $\begin{array}{c}0.451 \\
{[0.498]}\end{array}$ & $\begin{array}{c}0.500 \\
{[0.500]}\end{array}$ & $\begin{array}{c}0.049 \\
(0.030)\end{array}$ & 2,083 & $\begin{array}{c}-0.065 \\
(0.043)\end{array}$ & 3,573 \\
\hline
\end{tabular}

Notes: "Living in Poverty" refers to living in a household with a family income below the poverty line, whereas "Living in Near Poverty" refers to living in a household with a family income below 1.5 times the poverty line. Standard deviations are in brackets and standard errors, clustered at the state level, are in parentheses. All regressions include a constant term. * $p<0.1 ; * * p<0.05 ; * * * p<0.01$.

Source: Authors' tabulations using the ACS 2009-2011, 2013-2014. 
Table 3: The Impact of Household Head DACA-Eligibility on Household Poverty [Sample: Skilled (HS+) Mexican Non-citizens 27-34 Years of Age Who Arrived Prior to Age 16]

\begin{tabular}{lcc}
\hline Key Regressors & Living in Poverty & \multicolumn{2}{c}{ Living in Near Poverty } \\
\hline \multirow{2}{*}{ DACA*Eligible } & Main Results [Sample: 2009-2011 \& 2013-2014] \\
Eligible & $-0.106^{* * *}$ & -0.061 \\
& $(0.035)$ & $(0.058)$ \\
Dependent Variable Mean & 0.035 & -0.004 \\
Observations & $(0.044)$ & $0.051)$ \\
R-squared & 0.281 & 0.467 \\
\hline
\end{tabular}

Notes: "Living in Poverty" refers to living in a household with a family income below the poverty line, whereas "Living in Near Poverty" refers to living in a household with a family income below 1.5 times the poverty line. All regressions include a constant term. Other covariates include: age and age-at-arrival dummies, gender, race, marital status and educational attainment of the household head; family size; and controls for the level of state immigration enforcement, the existence of 'in-state tuition for undocumented immigrants' and the unemployment rate in the state where the migrant resides. The state enforcement variable is an indicator for whether the individual resides in a state with any of the following immigration enforcement measures: an employment verification (E-Verify) mandate, an omnibus immigration law or a signed state-wide 287(g) agreement with Immigration Custom Enforcement (ICE). The 'in-state-tuition' variable is an indicator for residing in a state granting in-state tuition for undocumented immigrants. Additionally, all specifications include state fixed effects, year fixed effects, and state-specific linear time trends. Standard errors are clustered at the state level. $* p<0.1 ; * * p<0.05 ; * * * p<0.01$. 
Figure 1: Coefficients and 95\% Confidence Intervals from Poverty Regression

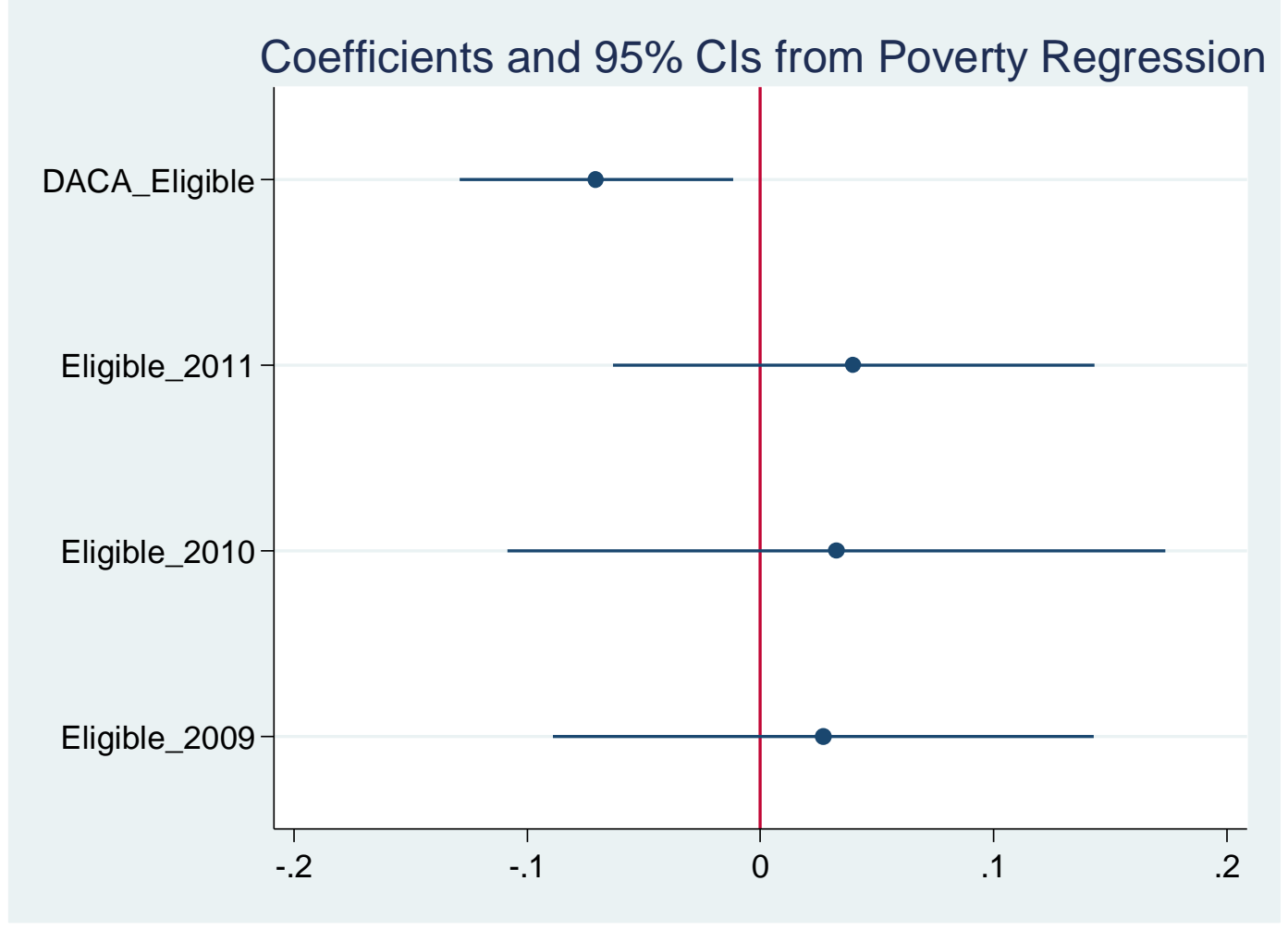

Notes: Graph shows coefficient estimates and confidence intervals from regression of indicator for living in poverty on the interactions between eligibility status and DACA period (2013 and $2014)$ as well as eligibility status and vector of year dummies prior to DACA (2009, 2010, and 2011). Note that the inclusion of all interaction terms absorbs the main effect of eligibility status, which is thus omitted from the specification. Other covariates include: age and age-atarrival dummies, gender, race, marital status and educational attainment of the household head; family size; and controls for the level of state immigration enforcement, the existence of 'instate tuition for undocumented immigrants' and the unemployment rate in the state where the migrant resides. The state enforcement variable is an indicator for whether the individual resides in a state with any of the following immigration enforcement measures: an employment verification (E-Verify) mandate, an omnibus immigration law or a signed state-wide $287(\mathrm{~g})$ agreement with Immigration Custom Enforcement (ICE). The 'in-state-tuition' variable is an indicator for residing in a state granting in-state tuition for undocumented immigrants. State fixed effects, year fixed effects, and state-specific linear time trends are also included in the specification. Standard errors are clustered at the state level. 